\title{
Cólico nefrítico, teratoma ovárico y radiografía simple de aparato urinario
}

\author{
Romero Pérez P, Martínez Hernández Mㅡㄹ. \\ Servicio de Urología. Policlínico San Carlos Denia (Alicante).
}

Actas Urol Esp. 2007:31(8):936-937

$\mathrm{L}$ a radiografía simple de aparato urinario utilizada como exploración inicial del cólico nefrítico, puede ayudar en el diagnostico diferencial de determinados casos e intuir el diagnóstico de la patología ovárica asociada en la mujer.

Se presenta el caso ilustrativo de una paciente de 27 años sin antecedentes patológicos de interés, que consultó a su médico de cabecera por dolor en fosa renal derecha irradiado a hemiabdomen inferior derecho. Nos fue remitida ya asintomática para estudio de posible cólico

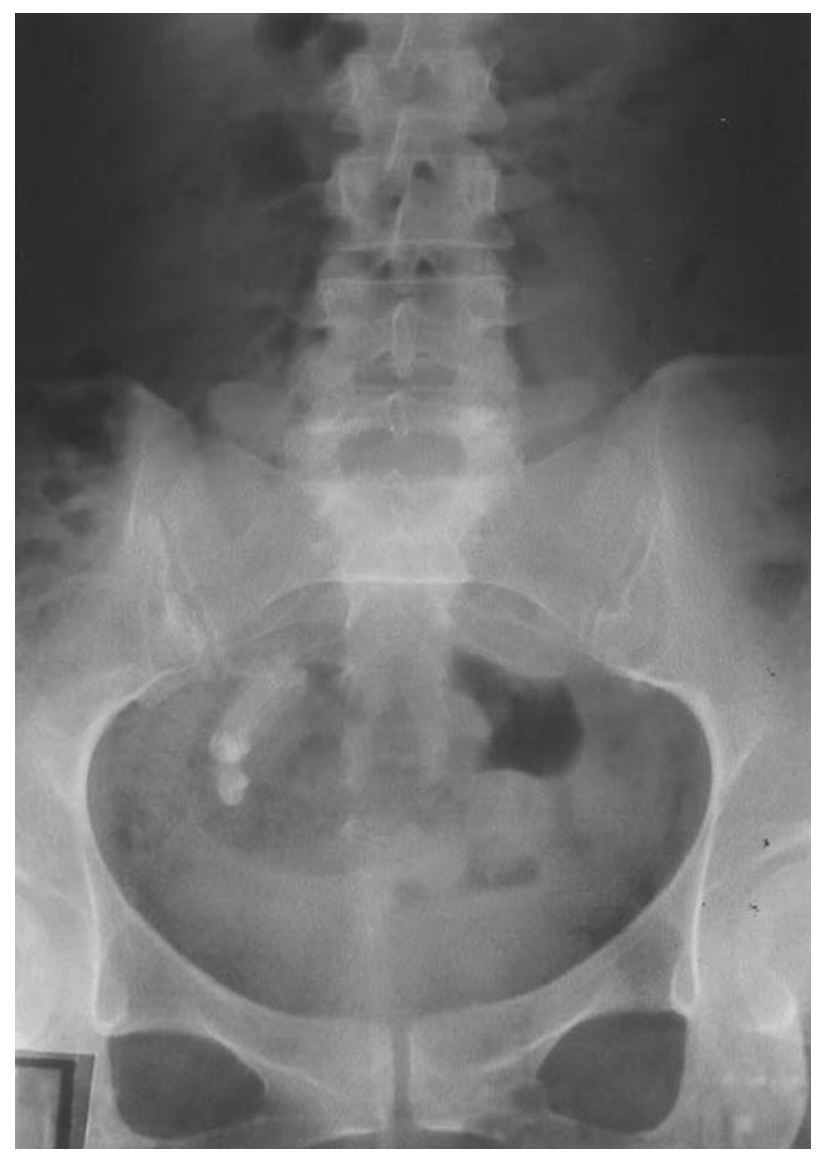

FIGURA 1 nefrítico derecho. Se solicitó radiografía simple de aparato urinario en la que como hallazgo más significativo se apreció la existencia de 2 imágenes radiopacas en hemipelvis ósea derecha que semejaban a tejido dental (dientes) (Figs. 1 y 2). Se solicitó ecografía renovesical que fue normal. La ecografía pélvica mostró una tumoración de ovario derecho por posible teratoma ovárico. Con el diagnóstico de teratoma ovárico derecho fue remitida a Ginecología para tratamiento quirúrgico, que confirmó dicho diagnóstico.

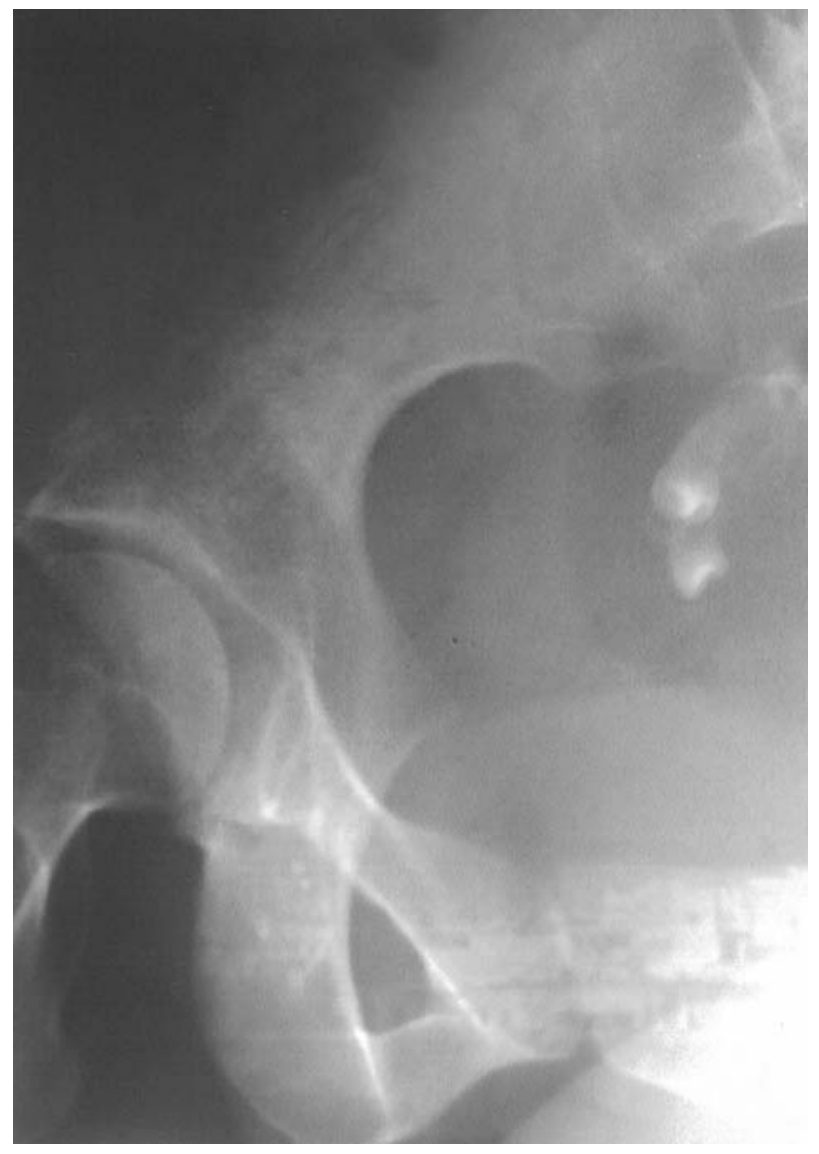

FIGURA 2 
En referencia al caso que nos ocupa, más del 95\% de los quistes dermoides se originan en el ovario. La cápsula del quiste es bastante radiopaca y el líquido oleoso que contiene es radiolúcido; esta combinación origina a veces un aspecto radiólogico de calcificación en la pared del quiste. Este puede contener elementos derivados de cualquier estructura ectodérmica, como por ejemplo pelos, dientes, o material sebáceo, lo que facilita su identificación, como en el caso que presentamos.

En la histogénesis de los tumores ováricos, se distinguen tumores epiteliales, tumores germinales, tumores del estroma y tumores secundarios (tumor de Krukemberg). Los tumores germinales del ovario derivan de células germinales que se originan en el saco vitelino y emigran hacia la línea media hasta la pared posterior del celoma abdominal. Son estructuralmente iguales a los testiculares, pero el microambiente determina diferentes comportamientos biológicos. Entre ellos el disgerminona, el carcinoma embrionario, el coriocarcinoma y el tumor del seno endodérmico son raros en el ovario. Por el contrario el teratoma quístico es muy frecuente, y es absolutamente benigno (no ocurre lo mismo en el teratoma testicular que puede ser maligno). En ginecopatología al teratoma ovárico se le denomina quiste dermoide ${ }^{1}$.

Se hace énfasis sobre la radiografia simple de aparato urinario ( $R x S A U$ ), que sigue siendo una exploración radiológica válida para el enfoque inicial del cólico nefrítico, si bien es verdad que, en determinados casos, debe complementarse con un estudio ecográfico renovesical o un TAC si los hallazgos no son concluyentes o diagnósticos.

En la Rx SAU se pueden apreciar gran cantidad de sombras extraurinarias que se prestan a confusión (sombras radiopacas u opacidades que simulan la densidad de material calcificado o de medios de contraste en el tracto urinario) ${ }^{2}$, entre ellas figuran: sombras de los cartílagos costales y de las apófisis transversas de las vértebras lumbares (cartílagos costales calcificados), sombras que se originan en la superficie del cuerpo (vendajes, ropas, botones, hebillas), calcificación de los vasos sanguíneos (los más frecuentes con diferencia son los flebolitos de las venas pélvicas que aparecen en la radiografía en la región de la vejiga y otras veces son calcificaciones de las arterias ilíacas, de la aorta abdominal, vasos renales, o esplénicos y aneurismas de la aorta y de las arterias renales o esplénicas), calcificación de las es- tructuras intraabdominales (hígado "quiste hidatidico y absceso calcificado", bazo, tracto biliar, páncreas, ganglios linfáticos mesentéricos o retroperitoneales y glándulas suprarrenales), huesos de un feto de una mujer embarazada o calcificación de un feto extrauterino muerto "litopedion", sombras de calcificación varias (tumores malignos o hematomas retroperitoneales, o abscesos de psoas calcificados), opacidad de la vesícula biliar producida por una colecistografia previa, residuos de la medicación subcutánea o intramuscular (oleomas o granulomas glúteos o sales de metales pesados por tratamiento antisifilitico o aceite yodado de mielografia), material opaco en el intestino (perdigones de caza, bario residual, pastillas no disueltas con cubierta entérica), sombras consecuentes a intervenciones quirúrgicas previas (fusión quirúrgica de vértebras lumbares o sacras, semillas de isótopos radiactivos, suturas metálicas, grapas, mallas herniarias de tantalio), las sombras con origen en la pelvis $y$ tracto genital femeninos a saber: mallas o grapas de cirugía anti-incontinencia, pesarios, tampones vaginales, esponja de gasas intravaginales polvos y residuos de la insuflación tubárica, fibroadenoma uterino calcificado, carcinoma de ovario, apéndice y uraco "calcificación de adenocarcinoma productor de moco o "pseudomixoma peritoneal" y los quiste de uraco calcificados, y en el sexo femenino los quistes dermoides de ovario (teratomas ováricos), que contienen dientes y por ultimo sombras con origen en la pelvis y tracto genital masculino: calcificación del tracto espermatico ${ }^{3}$ (conducto deferente, ampolla del conducto deferente y vesículas seminales), calcificaciones prostáticas, y calcificación del cuerpo cavernoso de la enfermedad de La Peyronie).

\section{REFERENCIAS}

1. Contreras F, Suárez A, Palacio J: Histogénesis de los tumores ováricos. En: "M. Gonzalez Barón. Tumores gonadales: Aspectos clínicos y terapéuticos”. Pág. 61-67, Editorial MCR, S.A. Barcelona 1985.

2. Witten DM, Myers GH, Utz DC: La radiografía simple del tracto urinario. En: "Emmett Urografía Clínica. Atlas y tratado de diagnóstico roentgenológico". Tomo I, cap.7, pág.399-485, Salvat Editores S.A., Barcelona 1982.

3. Romero Pérez P. Calcificación distrófica de conducto deferente en paciente diabético vasectomizado: imagen histológica. Actas Urol Esp 2002;26(5):380.

Correspondencia autor: Dr. P. Romero Pérez

Policlínico San Carlos de Denia. Madrigueres, sud A-14 03700 Denia (Alicante). Tel.: 965781558

E-mail: promeropez@gmail.com

Información artículo: Imágenes en Urología

Trabajo recibido: julio 2006

Trabajo aceptado: septiembre 2006 